contains very little morainic material, although scattered boulders occur on the glacier surface for $200 \mathrm{~m}$. or more from its lateral margin as a result of wind ablation.

A small moraine is forming at the present edge of the ice, and retreat of the terminal face of the dry valley lobe is recorded by another four, or possibly five, stranded terminal moraines (Fig. I). These are distinct, but are small because the glacier is slow and contains very little moraine. Vague traces of even older terminal moraines in the same series are visible on the floor of the dry valley further up-stream from the glacier snout.

There is no direct evidence of the age of the moraines but they have a recent appearance, and it is tempting to correlate the latest three of them with moraines occurring in the temperate latitudes in both hemispheres, such as the 1820,1850 and 1890 moraines of the European Alps, and three correlative moraines of the Hooker Glacier in New Zealand. ${ }^{2}, 3$ It has been questioned whether climatic changes occur simultaneously and in the same direction towards greater coolness or warmth in the Antarctic and in temperate regions. It has been suggested also that warming of the Antarctic leads to increased snowfall and expansion of glaciers there. If the Taylor Glacier moraines are correlatives of the European moraines, then the implications follow, first that recent climatic changes have been contemporaneous and in the same direction (towards warming) in both regions, and secondly that warming of the Antarctic, at least in the Taylor Glacier region, leads to contraction of glaciers. Until the Taylor Glacier moraines can be dated by some means these implications must be treated with reserve, but they do not conflict with independent evidence provided by cores of Ross Sea sediments, ${ }^{4}$ by a radiocarbon date, ${ }^{5}$ and by measurement of the temperature profile in a deep drill hole in ice at Byrd Station. ${ }^{6}$

The Taylor Glacier apparently drains a large area of the Plateau, but the retreat of its dry-valley lobe has been relatively very small. This suggests that associated changes in the level of the Plateau have probably been so small that they may not be detected by observation of the lower limit of lichen colonization of nunataks.

I6 July 1959

H. J. Harrington,
Geology Department,
University of New Engiand,
Armidale, N.S.W.,
Australia

I. G. Speden,
Geological Survey,
Box 368 ,
Lower Hutt,
New Zealand

\title{
REFERENGES
}

I. Ferrar, H. T. Report on the field-geology of the region explored during the "Discovery" Antarctic Expedition, r 90I-04. (In Geology. London, British Museum (Nat. Hist.), 1907. (National Antarctic Expedition, r9or-
r 904 . Natural History, Vol. I.))

2. Harrington, H. J. Glacier wasting and retreat in the Southern Alps of New Zealand. Journal of Glaciology,
Vol. 2, No. 12, 1952, p. 140-45. 3. McKellar, I. C. Stranded moraines of the Hooker and Mueller Glaciers. New Zealand Journal of Science and
Technology, Sect. B, Vol. 37, No. 2, 1955, p. 221-23. 4. Hough, J. L. Sediment distribution in the Southern Oceans around Antarctica. Fournal of Sedimentary Petrology,
Vol. 26, No. 4, I 956, p. 301-06.

5. Harrington, H. J., and McKellar, I. C. A radiocarbon date for penguin colonization of Cape Hallett, Antarctica. New Zealand Journal of Geology and Geophysics, Vol. 1, No. 3, 1958, p. 57 1-76.

6. Wexler, H. Geothermal heat and glacial growth. Journal of Glaciology, Vol. 3, No. 25, r959, p. 420-25.

SIR,

\section{Geothermal heat and glacial growth}

I can only admire the article of Dr. H. Wexler in the March 1959 number, ${ }^{1}$ and the novel application of his equations. But it seems to me that, in addition to the $3 \mathrm{r} \cdot 6 \mathrm{cal} . \mathrm{cm} \cdot .^{-2} \mathrm{yr} .^{-1}$ geothermal heat flux which he uses for $F_{\mathrm{o}}$ in these equations, there should also be added the heat of friction if the glacier is in a steady state yet accumulating $30 \mathrm{~cm}$. of ice per annum (if it were motionless, the steady state could not be). Nor is the heat of friction difficult to compute $-30 \mathrm{~cm} .(25 \mathrm{~g}$.) of ice added over the length of any glacier $3,000 \mathrm{~m}$. thick is the equivalent of $25 \mathrm{~g}$. falling $3,000 \mathrm{~m}$. in one year over each square centimeter of surface. This gives about $7 \times 10^{9} \mathrm{ergs}$, or $150 \mathrm{cal} . \mathrm{cm}^{-2} \mathrm{yr} .{ }^{-1}$, five times the geothermal heat flux! No appreciable amount of this work could have been syphoned off as kinetic energy of the moving glacier before conversion into heat; even at a velocity of $100 \mathrm{~m} . \mathrm{yr}^{-1}{ }^{-1}$ for the glacier, the kinetic energy of that ice column would be quite negligibly small.

Also as regards the value of $K$, the thermal conductivity of the glacier ice, which Wexler takes as 
$5.3 \times 10^{-3}$, I believe that the coefficient for any Arctic-type ice of density 0.88 or so (conpared with $0.9^{2} \mathrm{~g} . \mathrm{cm}^{-3}$ for laboratory ice) will be substantially less, due to "resistance" to heat flow by included air bubbles (the extreme case, snow, is a great thermal insulator). For the same reason $\kappa$, the thermal diffusivity, will also be less. So with a much larger supply of bottom heat, and a lower thermal conductivity and lower diffusivity, I believe that the family of curves in Wexler's fig. 2-at least all curves for times over 10,000 years-will ground themselves at a temperature just below $0^{\circ} \mathrm{C}$., implying that the basal region of any accumulating, thick glacier which is in a stable state will consist of isothermal ice, a conclusion of importance in considering the even thicker Pleistocene ice sheets.

In order to give some idea of the thermal conductivity of bubbly ice, I have had my guide, Armand Perron of Valtournanche, make a series of measurements which should approximate a comparison of the thermal conductivity of normal (isothermal) glacier ice of density $0.9^{2}$ in the Gornergletscher (altitude $2,800 \mathrm{~m}$.) with that of bubbly (isothermal) glacier ice, density 0.87 , in the same glacier. Illustrations of small specimens of these two types of ice from the same area were reproduced in an earlier paper. ${ }^{2}$ These tests were made by inserting aluminum tubes containing refrigerated brine mixtures at about $-9^{\circ} \mathrm{C}$. into close-fitting bore holes in the two types of ice in situ, and by measuring the time interval for the respective tubes of cold brine to warm up to the temperature $\left(0^{\circ} \mathrm{G}\right.$.) of the surrounding glacier ice. The tubes inserted in normal glacier ice required on the average $21 \mathrm{~min}$.; those in the bubbly ice, $4^{2} \mathrm{~min}$. It would seem that there is a very substantially lower thermal conductivity for bubby ice compared with normal ice, of the order of one half.

Also, on this same subject, Birch and Clark ${ }^{3}$ report substantially lower thermal conductivity for limestone, marble, and even for gabbro and diabase compared with the conductivities, suitably weighted, of their constituent minerals - due, they show, to the minutest films and wedges of air or other gases between the mineral crystals. Such differences of conductivity run up to some 20 per cent for these rocks; if in rock the minute remnants of air persisting between mineral crystals after millions of years of exposure to thousands of tons pressure at high temperature cause such differences, it seems probable that substantially greater diminution of thermal conductivity occurs in cold firn, in which occluded air has only had a few thousand years to escape under only a few thousand pounds pressure. Both in rock and ice it is the breaking up of continuous paths by multiple minute air spaces, rather than the resulting slightly lesser density, which decreases thermal conductivity. I am planning measurements in the field of the thermal conductivity of this cold firn, probably at $4,000 \mathrm{~m}$. on the Monte Rosa, this summer or next.

But the original method of attack by Dr. Wexler has my admiration! I thank him.

25 West 43 rd Street,

New York 36, N.Y., U.S.A.

I6 July 1959

SIR,

I appreciate the opportunity to comment on Mr. Fisher's interesting suggestions.

in my calculations I assumed the ice to be contained and motionless within the Marie Byrd Land basin-a non-steady state condition both with respect to temperature and mass. If a layer of ice is moving then certainly friction will introduce another heat source; but whereas geothermal heat is supplied at the bottom of the ice, this is not true for frictional heating released by sinking ice layers. It is difficult to see how surface layers could make their way to the bottom of the ice as Mr. Fisher postulates. An ice mass moving horizontally would have to be of infinite extent to enable layers deposited on the surface eventually to move close to the bottom. For an ice mass moving down a slope, the ice trajectories within the glacier would dip down in the accumulation zone, but move up again to the surface in the ablation zone. Thus it is likely that the heat of friction released by vertical motion of the ice layers is not concentrated at the bottom of the ice.

With regard to the thermal conductivity of glacier ice, I found Mr. Fisher's description of thermal conductivity experiments on "normal" and "bubbly" glacier ice to be of considerable interest. If the thermal conductivity of the bubbly ice is only half the normal value of $5.3 \times 10^{-3} \mathrm{c} . g . s$. units, and if this ice is the same as that resting on bedrock under $3,000 \mathrm{~m}$. of ice in Marie Byrd Land, then after 10,000 years the bottom temperature would become $-13.0^{\circ} \mathrm{C}$. instead of $-18.5^{\circ} \mathrm{C}$. as originally computed for the case of no loss of geothermal heat through the ice. This new value is based on an ice density of 0.87 , as given by $\mathrm{Mr}$. Fisher. Using the density of pure ice, 0.92 , the temperature would be $-13.4^{\circ} \mathrm{C}$. 